\title{
Characterization and identification of three thermophilic Bacillus strain isolated from Domas Crater, Mt. Tangkuban Perahu, Indonesia
}

\author{
RATU SAFITRI ${ }^{1,2}$, DELICIA PUTRI KUSUMAWARDHANI ${ }^{1}$, ANNISA $^{1}$, RUHYAT PARTASASMITA $^{1, \bullet}$, \\ SINTA ASHARINA ${ }^{3}$, ANI MELANI MASKOEN ${ }^{4}$ \\ ${ }^{1}$ Department of Biology, Faculty of Mathematics and Natural Sciences, Universitas Padjadjaran. Jl. Raya Bandung-Sumedang Km 21, Jatinangor, Sumedang \\ 45363, West Java, Indonesia. Tel.: +62-22-7796412 ext. 104, Fax.: +62-22-7794545, `email: rp2010rikkyo@gmail.com; ruhyat.partasasmita@unpad.ac.id \\ ${ }^{2}$ Biotechnology Program, Postgraduate Program, Universitas Padjadjaran. Jl. Dipati Ukur No. 35 Bandung, 40132, West Java, Indonesia. \\ ${ }^{3}$ Microbiology and Parasitology Laboratory, Faculty of Medicine, Universitas Padjadjaran. Jl. Raya Bandung-Sumedang Km 21, Jatinangor, Sumedang \\ 45363, West Java, Indonesia \\ ${ }^{4}$ Faculty of Dentistry, Universitas Padjadjaran. Jl. Raya Bandung-Sumedang Km 21, Jatinangor, Sumedang 45363, West Java, Indonesia
}

Manuscript received: 20 December 2019. Revision accepted: 4 July 2020.

\begin{abstract}
Safitri R, Kusumawardhani PD, Annisa, Partasasmita R, Asharina S, Maskoen AM. 2020. Characterization and identification of three thermophilic Bacillus strains isolated from Domas Crater, Mt. Tangkuban Perahu, Indonesia. Biodiversitas 21: $3444-3453$. A community of thermophiles within the hot spring of Domas Crater, Mount Tangkuban West Java, has been cultivated and identified based on the $16 \mathrm{~S}$ ribosomal RNA gene sequence. The hot spring has a temperature of $45^{\circ} \mathrm{C}-76{ }^{\circ} \mathrm{C}, \mathrm{pH} 1-2$, the isolate has been cultivated in Thermus medium at a temperature of 70 and $\mathrm{pH}$ 6. The three isolated strains were L61A, TS61A, and D41A identified based on the 16S ribosomal RNA gene sequence refer to the GenBank database and all of them belong to the Phylum Firmicutes, which are clustered within the taxonomic groups of Bacillus, the Bacillus, and Geobacillus genera. Nucleotide sequences were compared for homology with BLASTN search at the NCBI Web-site revealed that strains (L61A) had $99.93 \%$ similarity with Geobacillus uzenensis. TS61A strain has a $99.24 \%$ similarity with Bacillus wiedmannii. Whereas D41A has $99.79 \%$ similarity with Bacillus paramycoides. The characterization also includes the phenotypic and biochemical of strains. The bacillus genera were known as a source of thermostable enzymes, plant growth-promoting, probiotics, decomposers of various polysaccharide materials, and bioremediation.
\end{abstract}

Keywords: Thermophilic, Mount Tangkuban Perahu, 16S rRNA, Geobacillus uzenensis, Bacillus wiedmannii, Bacillus paramycoides

\section{INTRODUCTION}

In the early 1970 s, Sulfolobus species had been found in Solfatara fields, and mud springs around the world and Sulfolobus acidocaldarius have been successfully isolated from Yellowstone Park by Thomas Brock and co-workers (Brouns et al. 2006). Thermoplasma acidophilum has no walls that can also be isolated from the sulfuric acid environment of coal waste, and Thermoplasma volcanium spp can be isolated from solfataric hot springs in Italy. In Indonesia, precisely from the volcano area, Mt. Tangkuban perahu also found Sulfolobus and Thermoplasma species (Sri Handayani et al. 2012). In the Laboratory, Thermoplasma acidophilum grows at $\mathrm{pH} 1$ to 4 and the optimal growth temperature of 39 and $59{ }^{\circ} \mathrm{C}$. Sulfolobus spp., grow autotrophically in solfatara fields preferentially around temperatures of $80-85^{\circ} \mathrm{C}$ (Luthfa, et al. 2015).

According to Quehenberger et al. (2017), Sulfolobus grow at $\mathrm{pH} 2-3$ and temperatures around $75-80{ }^{\circ} \mathrm{C}$ and characterized as chemoorgano heterotrophic. However, it has been reported for some species as chemolithoautotrophic growth using sulfur oxidation. Thermoplasma lacks a cell wall, and only have membrane lipids. Both of Sulfolobales and Thermoplasmatales members grow autotrophically metabolizing elemental sulfur, but can also grow mixo- and heterotrophically, from anoxic to oxic conditions (Handayani et al. 2012).
Besides Archaea which occupies harsh habitats, some of the Genus Bacillus inhabits areas from ocean sediments thousands of meters below sea level, also in stratospheric water. The genus Bacillus is one of the thermophiles with unique features because of its ability to inhabit extreme conditions.

Extremophiles are taxonomically widely distributed and are a functionally diverse group that includes acidophilic, growing optimally $\mathrm{pH} 1-5$; alkaliphilic, growing optimally above $\mathrm{pH}$ 9; halophilic, growing optimally in an environment of high salt concentration; thermophilic, growing optimally at $45-70^{\circ} \mathrm{C}$; hyperthermophilic growing optimally at temperatures above $70^{\circ} \mathrm{C}$; barophilic growing optimally growth at high hydrostatic pressure; oligotrophic, showing optimum growth in nutrient-limited environments; endolithic, growing in rocks or mineral pores; and xerophilic, growing under conditions of low water availability (Niederberger 2016).

Some Bacillus species are isolated from acidic geothermal pools and peat bogs; they have been found in hypersaline terminal lakes and tolerant to heavy metals (Zeigler and Perkins 2009; Panosyan 2017; Liu et al. 2017). Geobacillus uzenensis was moderately thermophilic, had an optimum temperature of $45^{\circ} \mathrm{C}-65^{\circ} \mathrm{C}$, was isolated from formation waters of oilfields (Nazina et al. 2001). Thermophiles isolated from Tanjung Sakti Hot Spring (South Sumatra), 
which has a temperature of $80^{\circ} \mathrm{C}-91^{\circ} \mathrm{C}, \mathrm{pH} 7-8$, culture is incubated at a temperature of $55^{\circ} \mathrm{C}$ on a nutrient broth medium. Strains were identified based on $16 \mathrm{~S}$ ribosomal RNA gene sequences obtained by four distinct taxonomic groups: Anoxybacillus, Geobacillus, Brevibacillus, and Bacillus. These microbes are closely related to Anoxybacillus rupiensis, Anoxybacillus flavithermus, Geobacillus pallidus, and Bacillus, Brevibacillus thermoruber, Bacillus licheniformis, and Bacillus thermoamylovorans (Yohandini et al. 2015). The factors affecting heat tolerance of thermophilic organisms are the chemical stability of their membrane lipids; the dynamic proportion of diether lipids to increase in temperature (Mehta et al. 2016); the content of rRNA and tRNA molecules of thermophilic bacteria having higher $\mathrm{G}: \mathrm{C}$; $\mathrm{GC}$ base pair forming more hydrogen bonds; and higher $\mathrm{G}: \mathrm{C}$ contents in the double-stranded stem region improving thermostability of the RNA molecules (Paz et al. 2004).

Thermophile Bacillus is one source of biodiversity that is a source of various genes, thermozymes, and other metabolites that are very promising. These enzymes stable in high-temperature conditions, chemicals, and $\mathrm{pH}$, making them ideal for industrial applications. Also, that can be suitable for performing biological and biotechnological processes at elevated temperatures (Zeigler and Perkins 2009; Cihan et al. 2012). Thermozymes are thermostable enzymes such as amylases, cellulases, chitinases, pectinases, xylanases, proteases, lipases, pullulanase, laccase, and DNA polymerases. Those thermozymes are products of thermophiles that receive more attention because they have a vital role in the food, chemical, pharmaceutical, paper, pulp, and waste-treatment industries (Zeigler and Perkins 2009; Cihan et al. 2011). Thermostable xylanase from a Geobacillus sp. strain isolated from a gold mine (Siso et al. 2019).

Moreover, thermozymes are reported to be more stable against many solvents, detergents, and acidic and alkaline pH (Kambourova et al. 2018). Thermozyms have many advantages performing processes at higher temperatures, are reduced risk of microbial contamination, lower viscosity, improved transfer rates, and improved solubility of substrates. However, cofactors, substrates, or products might be unstable, or other side reactions may occur. Alkaline protease possesses the property of high stability when used in detergents. Cellulases are very potential to be applied to feed products made from organic waste (Bosma et al. 2015).

Plants, fruits, and vegetables also the source of the novel Bacillus species, some endophytic, and others rhizosphere-associated. The two thermophilic genera were the aerobic Geobacillus and the anaerobic Anoxybacillus. The Bacillus species has played a crucial role in establishing a wide range of sustainable industrial fermentation processes, which in some cases (e.g., riboflavin), antibiotics, vitamins, increases essential amino acids, proteases, lipases, amylases, and carboxypeptidases.

Study of the diversity of the Bacillus community in the hot spring crater of Domas Mt. Tangkuban Parahu has not been done much. The purpose of this study is to explore and characterize thermophile Bacillus for the culture collection for further research. The genera bacillus was known as a source of thermostable enzymes, secondary metabolites, probiotics, decomposers of various polysaccharide materials, and bioremediation.

\section{MATERIALS AND METHODS}

\section{Samples collection and characterization}

Research using exploratory methods and analyzed data descriptively. Strains were isolated from the Hot Spring of the Domas Crater, located in nortern Bandung, West Java, Indonesia. Samples were cultivated on the Thermus medium to grow. Then the culture was grown on a solid Thermus medium by adding Gellrite (2\%). The growing colonies were then isolated. The isolate was grown at 700C in the Thermus medium with components of 0.3 gram of $\mathrm{KH}_{2} \mathrm{PO}_{4}, 0.25$ gram of $\mathrm{MgSO}_{4} .7 \mathrm{H}_{2} \mathrm{O}, 0.125$ gram of $\mathrm{CaCl}_{2} \cdot 2 \mathrm{H}_{2} \mathrm{O}, 1$ gram of $\left(\mathrm{NH}_{4}\right) \mathrm{SO}_{4}, 2$ grams of yeast extract, 4 grams of peptone, and 1 gram of $\mathrm{NaCl}$. All routine DNA isolation and manipulations were performed as described by Sambrook and Russell (2001) and BBPT (2019). Characterization included the study of phenotypic, isolate growth on Thermus medium, $\mathrm{pH}$ optimization (4 and 6) and temperature optimization (at $60^{\circ} \mathrm{C}$ and $70^{\circ} \mathrm{C}$ ), morphological characterization of isolates and biochemical tests on saccharose, lactose, glucose, maltose and mannitol, TSIA, urea, indole, methyl red, Voges Proskauer, and Simon citrate. Three isolates were obtained, namely, L61A, TS61A, and D41A.

The bacterial growth is determined by the Total Plate Count method. The bacterial suspension is based on McFarland 1, with several cells equal to $3 \times 10^{8}$ bacterial cells $/ \mathrm{mL}$. A suspension of $1 \%$ of bacterial is grown in a Thermus medium at $\mathrm{pH} 4$ and 6 , and the number of cells reaches $3 \times 10^{6}$ cells $/ \mathrm{mL}$. Bacteria were incubated at $60^{\circ} \mathrm{C}$ and $70^{\circ} \mathrm{C}$. Bacterial growth was measured using the turbidimetric and the Standard Plate Count (SPC) technique. The bacterial growth phase was measured by Optical Density (OD) on a spectrophotometer with a wavelength of $600 \mathrm{~nm}$ (Zhou et al. 2016; Tominaga et al. 2016). The bacterial growth by the TPC method was measured every 6 hours for 54 hours.

\section{Identification using Polymerase Chain Reaction (PCR) 16S rDNA amplification and sequencing}

Genomic DNA was extracted and purified according to Sambrook and Russell (2001). DNA samples were extracted using the InstaGene ${ }^{\mathrm{TM}}$ (Biorad) matrix kit, followed by amplification. Sequencing of $16 \mathrm{~S}$ rRNA of the isolate and amplification of the target gene was done using the universal bacterial primer 1492R 5'CCTTGTTACGACTT-3' and the domain bacteria-specific primer 27F 5'- AGAGTTTGATCCTGGCTCAG-3'.

The purification of PCR products was carried out using a $10 \mu \mathrm{L}$ Purification Binding Membrane Wizard. SV Mini column is inserted into the collection tube. The PCR product mixture was added to the column, incubated for 1 minute and centrifuged $16,000 \mathrm{x} \mathrm{g}$ for 1 minute. The resulting supernatant is then discarded. The pellet in the 
mini-column is then put back into the collection tube. A membrane wash solution and ethanol were added as much as $700 \mu \mathrm{L}$, then centrifuged at $16,000 \mathrm{x} \mathrm{g}$ for 1 minute. The supernatant is then discarded while the mini-column is put back in the collection tube. The membrane washing solution and ethanol were added back by $500 \mu \mathrm{L}$ and centrifuged at $16,000 \mathrm{x}$ g for 5 minutes. The collection tube is emptied and re-centrifuged for 1 minute with an open microcentrifugation lid to allow the evaporation of ethanol residue. The min column is transferred to a clean microcentrifuge tube slowly. Nuclease free water is then added as much as $50 \mu \mathrm{L}$. After that, incubation was carried out at room temperature for 1 minute and centrifuged at $16,000 \mathrm{x} g$ for 1 minute. Mini columns are separated from DNA, while DNA is stored at $4^{\circ} \mathrm{C}$ or $-20^{\circ} \mathrm{C}$.

\section{Cycle sequence}

After the PCR product was purified, cycle sequencing was carried out using a single primer $27 \mathrm{~F}$ and $1942 \mathrm{R}$. The composition used for each tube was $3 \mu \mathrm{L} 5 \mathrm{x}$ buffer sequencing, $2 \mu \mathrm{L}$ primers, $1 \mu \mathrm{L}$ BigDye V.3.1 and $4 \mu \mathrm{L}$ DNA templates. The mixture was put into a $0.2 \mathrm{~mL}$ PCR tube. Furthermore, the amplification was performed with 25 cycles of PCR. The first heating at $96^{\circ} \mathrm{C}$ for 2 minutes, followed by a cycle consisting of denaturation for 10 seconds at $96^{\circ} \mathrm{C}$, annealing for 5 seconds at $55^{\circ} \mathrm{C}$ and the extension for 4 minutes at $60^{\circ} \mathrm{C}$ and cooling at $4^{\circ} \mathrm{C}$.

\section{Preparation and sequencing}

Preparation is done by mixing cycle sequencing products with $10 \mu \mathrm{L}$ of DNA and RNA free water, $5 \mu \mathrm{L}$ of $125 \mathrm{mM}$ EDTA solution, $3 \mu \mathrm{L}$ of Na-acetate $3 \mathrm{M}$ solution and $60 \mu \mathrm{L}$ of absolute ethanol. The sample was inverted $4 \mathrm{x}$ and incubated at room temperature for 15 minutes. Samples were centrifuged at $3,000 \mathrm{x} \mathrm{g}$ for 30 minutes. The supernatant is removed, $70 \mathrm{pL}$ of $70 \%$ ethanol is added to the pellet. The sample was then centrifuged at a speed of $1,650 \mathrm{x} g$ for 15 minutes. The supernatant is removed while the remaining $70 \%$ ethanol is removed by spindown, dried using the vacuum desiccator for 10 minutes, eluted with 10 $\mu \mathrm{L}$ of DNA and RNA free water, and heated with digital heat block at $42^{\circ} \mathrm{C}$ for 5 minutes. The solution was precipitated by centrifugation.

The DNA analysis was carried out using the BioEdit program to see the sequence of nitrogen bases. BLAST was carried out at Bank Gene NCBI data library (https://blast.ncbi.nlm.nih.gov/Blast.cgi). Ten sequences of BLAST results are taken and then a phylogeny tree made. The phylogeny tree was created using the MEGA $X$ program. The phylogeny test uses the Bootstrap method with 100 times replication. The substitution model used is the Kimura 2-parameter model while the type of substitution chosen is a nucleotide.

\section{RESULTS AND DISCUSSION}

\section{Enrichment and isolation}

To enrich aerobic endospore-forming thermophilic, bacteria samples in the form of mud or slurry and sediment samples as much as $5 \mathrm{~g}$ inoculated in the thermus medium at a temperature of $70^{\circ} \mathrm{C}$ ph 6 , the goal is to grow the thermophile isolates. After the growth isolates were observed through medium turbidity, bacterial samples were taken as much as $5 \mathrm{ml}$ to be inoculated in a liquid thermus medium incubated for one week at $60^{\circ} \mathrm{C}$. The gram staining was also performed to see the diversity of isolates. Subsequently, $500 \mu \mathrm{L}$ samples were taken to be grown on a solid thermus medium, incubated at $60^{\circ} \mathrm{C}$, and ph 6 . Colonies that grew in solid media were observed for their phenotypic morphology, repeatedly carried out to obtain pure thermophilic bacterial isolates.

\section{Cell morphology and colony characteristics}

The Hot Spring of The Crater of Domas Mt. Tangkuban Perahu (Figure 1) Was $76^{\circ} \mathrm{C}$ and $\mathrm{pH} 2$. Before inoculation on a medium incubated at $60{ }^{\circ} \mathrm{C}$, all samples were treated at $70^{\circ} \mathrm{C}$ for 24 hours to isolate thermophilic bacteria and spore-forming. Cultures showing different colony morphology were further purified by streaking samples on the same medium supplemented with gellrite $(2 \%, \mathrm{w} / \mathrm{v})$. All colonies obtained on plates were picked and purified by streaking onto the same medium at least three times. Subcultures that are considered pure are observed under a microscope showing a single morphological type. Isolates were tested for their colony morphology, Gram reaction, thermophilic growth, and catalase activity using commonly accepted methods. Bacteria that can live at temperatures of $50^{\circ} \mathrm{C}$ to $80^{\circ} \mathrm{C}$ are included in thermophilic bacteria (Niederberger 2016).

Three thermophile isolates are TS61A, L61A, and D41A, successfully grown at $60^{\circ} \mathrm{C}$ on a medium Thermus in $\mathrm{pH} 6$ (Figure 1). The TS61A colony (Figure $2 \mathrm{~A}$ ) is circular, white, gram-positive, short bacilli, with undulate margin, with flat-shaped elevation, gram-negative, growing at $\mathrm{pH} 4$, and 6. L61A colony (Figure $2 \mathrm{~B}$ ) is large circular, yellow, gram-positive, long bacilli with entire margin, with flat-shaped elevation, growing optimally at a temperature of $60^{\circ} \mathrm{C}$ and $\mathrm{pH} 6$, and occurring most dominantly among other bacteria. The D41A colony is round, white, circular, short bacilli with entire margin, convex elevation, growing at a temperature of $60^{\circ} \mathrm{C}$, and at $\mathrm{pH} 4-6$.

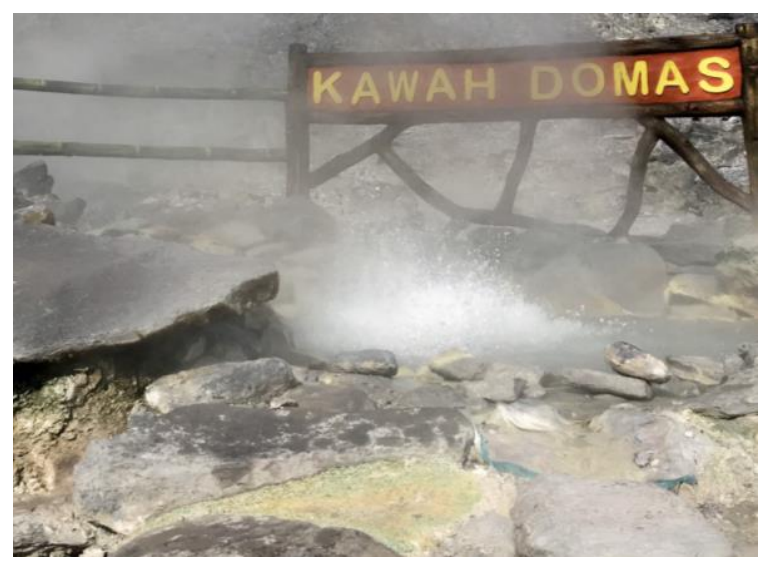

Figure 1. Site of thermophilic bacteria sampling at Domas Crater, Bandung, West Java, Indonesia 

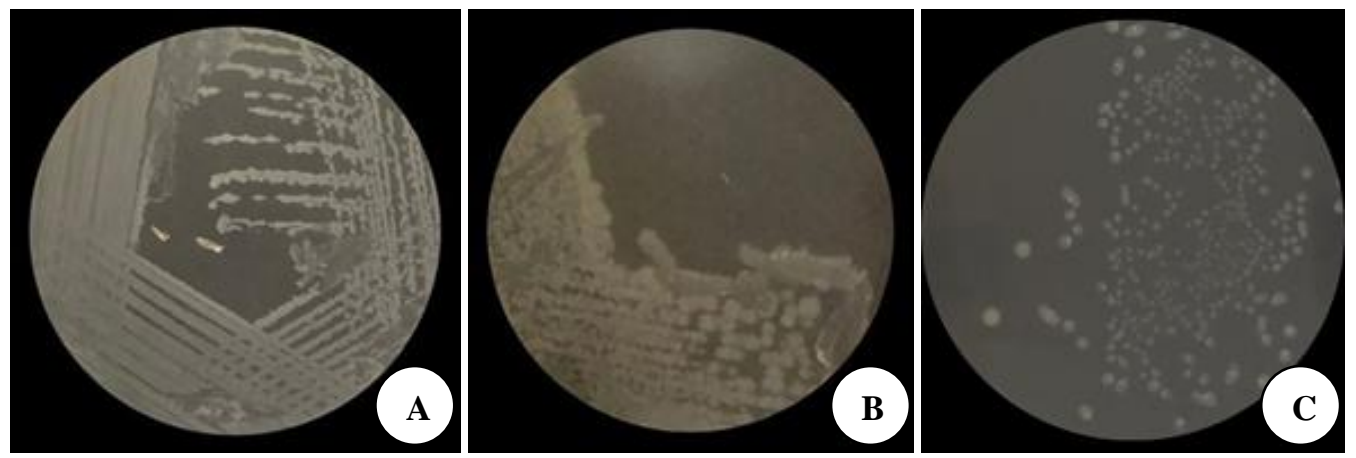

Figure 2. Morphological colonies of three thermophilic bacterial isolates from the Domas Crater, Bandung, West Java, Indonesia (A) TS61A (B) isolates L61A (C) isolates D41A

The three thermophilic strains of TS61A, D41A, and L61A showed positive catalase and oxidase. The presence of catalase was observed from the emergence of bubbles produced by the colony when dripped $\mathrm{H}_{2} \mathrm{O}_{2}$ while the oxidase activity was found through a change in color to purple when the colony was put on oxidase paper. The positive catalase and oxidase show that both bacteria can produce the enzymes catalase and oxidase. The catalase enzyme has a function to help convert hydrogen peroxide into $\mathrm{H}_{2} \mathrm{O}$ and $\mathrm{O}_{2}$, while the oxidase enzyme which functions to accelerate the combining of $\mathrm{O}_{2}$ with a substrate which at the same time also reduces $\mathrm{O}_{2}$ so that $\mathrm{H}_{2} \mathrm{O}$ is formed.

Bacilli show a positive catalase reaction, and thermophilic strains, $68 \%$ were highly oxidase-positive. Bacilli can be either obligate or facultative aerobes, they are known to form spores under stressful conditions, the ability to produce endospores allows Bacillus to survive extreme environmental conditions. These endospores are highly resistant to heat and radiation and are viable for extremely long periods. Bacillus species are Gram-positive rods often arranged in pairs or chains with rounded or square ends and usually have a single endospore but Some species may be Gram variable (PHE 2018). Most thermophilic strains show a positive reaction to the oxidase test. Thermophilic strains were grown at $65^{\circ} \mathrm{C}$, showing positive oxidase. Most mesophilic Bacillus strains and all of the psychrophiles examined were oxidase negative (PHE 2018).

Based on the results of the study shown in Table 1 . Strain TS61A can ferment glucose, mannitol, maltose, and saccharose medium after incubation for two days indicated by the change in color from red to orange on the medium. TS61A strain cannot ferment the lactose medium, as indicated by the remaining red in the lactose medium. The isolate of D41A grows optimally at $60^{\circ} \mathrm{C}$ and $\mathrm{pH} 6$.

Strain D41A ferment glucose, lactose, and maltose, as shown by the change from red to yellow in glucose, and orange in lactose and maltose. L61A isolate can ferment glucose, lactose, manite, and maltose, which is indicated by the yellow color of glucose, and the orange color of lactose, mannitol, and maltose. In indole, isolates TS61A, D41A, and L61A produced a negative reaction, indicating no triptonase enzyme, and therefore could not use tryptophan.
Strains TS61A, D41A, and L61A also produce negative reactions to Voges-Proskauer. TS61A and D41A strains in the methyl red test showed a change in color to red after the addition of the methyl red reagent and a $\mathrm{pH}$ decrease to $\mathrm{pH}$ 4, while the L61A in the methyl red test showed no color change.

A citrate test is a test that determines the ability of an organism or bacteria to use sodium citrate as the only source of carbon and ammonia salt as the only source of nitrogen. After 48 hours of incubation, the media changes color from green to blue. Tests on the Simon citrate medium, TS61A, D41A, and L61A strains produced a negative reaction. Also, on urea, the three strains show negative results, which means the three strains do not produce the urease enzyme. The testing of three strains on Triple Sugar Iron Agar (TSIA) showed a negative reaction.

Table 1. Phenotypic and biochemical characteristics of isolates from thermophilic L61A, TS61A, and D41A

\begin{tabular}{llll}
\hline Characteristic & TS61A & L61A & D41A \\
\hline pH tolerance & $4-7$ & $5-8$ & $4-6$ \\
Tolerance to temperature & $50-70^{\circ} \mathrm{C}$ & $37-75^{\circ} \mathrm{C}$ & $50-70^{\circ} \mathrm{C}$ \\
Optimum temperature & $60^{\circ} \mathrm{C}$ & $55-60^{\circ} \mathrm{C}$ & $60^{\circ} \mathrm{C}$ \\
Gram & - & + & - \\
Spores & + & + & - \\
Oxidase & + & + & + \\
Catalase & + & + & + \\
Glucose & + & + & + \\
Lactose & - & + & + \\
Mannit & + & + & - \\
Maltose & + & + & + \\
Saccharose & + & - & - \\
Indol & - & - & - \\
VP & - & - & - \\
MR & + & - & + \\
SC & - & - & - \\
Urea & - & - & - \\
TSIA & - & - & - \\
\hline
\end{tabular}


Based on the identification and characterization of the Bacillus cereus group, especially in several strains suspected Bacillus wiedmannii showed a positive reaction to acetoin produced in the Voges-Proskauer (VP) reaction, but all strains reacted negatively to hydrogen sulfide production, urease, tryptophan deaminase, and indole production. The utilization of citrate as a carbon source was variable (Miller et al. 2016).

In the genus Geobacillus which is isolated from subsurface from different oilfields, incubation was carried at $55 \pm 60^{\circ} \mathrm{C}$ in agar medium containing nitrate and acetate. Some strains can ferment cellobiose, galactose, glucose, fructose, glycerol, maltose, mannose, ribose, sucrose, and trehalose. No acid was formed from adonitol, inositol, lactose, raffinose, rhamnose, sorbitol, or xylose. The substrates used by all strains as energy and carbon sources included hydrocarbons. Strains failed to grow autotrophically. Generate a positive reaction to catalase, negative action on urea, indole, and Voges \pm Proskauer (Nazina et al. 2001) optimization of temperature and $\mathrm{pH}$

The observation of growth curves was carried out to determine the optimal growth of bacterial isolates by determining optimum $\mathrm{pH}$, temperature, and incubation time in the bacterial growth process. Bacterial growth was observed every 8 hours for 72 hours period. The number of bacteria is determined by measuring its absorbance using a spectrophotometer at a wavelength of $600 \mathrm{~nm}$. Graphic on bacterial growth is influenced by $\mathrm{pH}$ and temperature. From this graph, we obtained the optimum temperature and $\mathrm{pH}$ for bacterial growth.

Measurement of TS61A, D41A, and L61A strains bacterial growth was observed every eight hours using an optical density. Strain TS61A (Figure 3) grows more optimum at $60^{\circ} \mathrm{C}$ compared to $70^{\circ} \mathrm{C}$. The bacterial growth at $\mathrm{pH} \mathrm{4}$, better than $\mathrm{pH} 6$. However the difference in the average growth rate is not significant, this means that TS61A strains can grow well at acidic $\mathrm{pH}$ according to their habitat or have a $\mathrm{pH}$ tolerance of $4-6$ at $60^{\circ} \mathrm{C}$.

The L61A strain (Figure 4) grows optimally at $60^{\circ} \mathrm{C}$ compared to $70^{\circ} \mathrm{C}$ and is optimum at $\mathrm{pH} 4$ compared to $\mathrm{pH}$ 6 , this corresponds to the $\mathrm{pH}$ of the acidic hot spring $(\mathrm{pH}$ 2), but tolerant to $\mathrm{pH} 6$.

In Figure 4. The L61A strain has an optimum temperature of $60^{\circ} \mathrm{C}$ at $\mathrm{pH} 4$ and 6 , while at $\mathrm{pH} 7$, growth has decreased. The L61A strain has the optimum $\mathrm{pH}$ at $\mathrm{pH}$ 4 but is tolerant to $\mathrm{pH}$ 6. In Figure 5. D41A strain, similar to TS61A and L61A strains, has an optimum temperature of 60 and an optimum $\mathrm{pH}$ of 4.

\section{Genotypic identification}

Bacterial identification was carried out based on comparing 16S rRNA gene sequences of TS61A and L61A strains to the $16 \mathrm{~S}$ rRNA gene database in GenBank. Pure L61A and TS61A thermophile bacterial isolates were extracted DNA using the BIORAD InstaGene Matrix. DNA purity values were determined using DNA purity and concentration results using Thermo Scientific TM NanoDrop 2,000 with an OD ratio of 260/280 $\mathrm{nm}$.

Amplification of 16S rRNA genes from TS61A and L61A strains using $27 \mathrm{~F}$ and $1492 \mathrm{R}$ universal primers produced fragments in the range of $1000 \mathrm{bp}$ to $1500 \mathrm{bp}$ for L61A and 700 bp to 1000 bp strains for TS61A and D41A strains, and the results obtained in the form of DNA fragments measuring $1422 \mathrm{bp}$ (L61A) $679 \mathrm{bp}$ (TS61A) and 728 bp (D41A) was subsequently used for phylogenetic analysis.

The results of BLASTn strain L61A showed up to 99.93\% homology to the Geobacillus genus; The results on TS61A isolate showed up to $99.24 \%$ homology to the Bacillus genus, and that on D41A isolate showed homology to $99.79 \%$ with the genus Bacillus. Basic Local Alignment Search Tool (BLAST) is a tool used to find the appropriate sequences in a database of sequences to a sequence that you want to compare by comparing the local regions that have a high similarity between sequences in the database with sequences that are cytosine nucleotide bases. TS61A isolates have some differences with $B$. wiedmannii in the order of nucleotide bases. Site 418 TS61A shows thymine nucleotide base while $B$. wiedmannii shows a guanine nucleotide base.

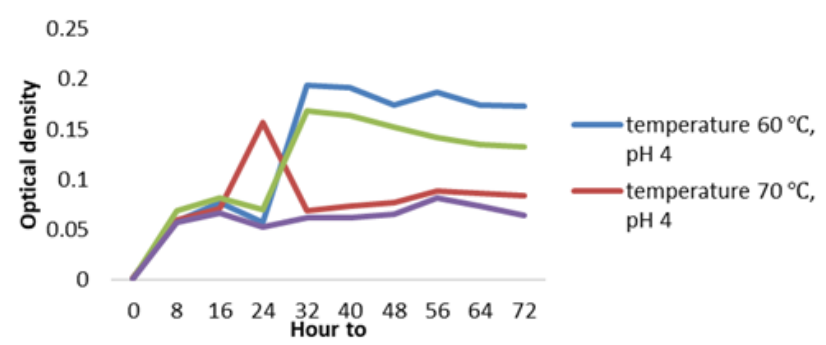

Figure 3. Growth curves of the TS61A strain at temperatures 60 and 70 and $\mathrm{pH} 4$ and 6.

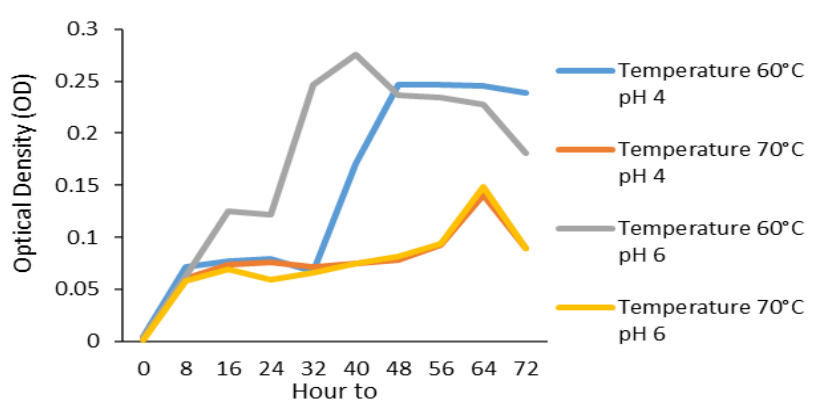

Figure 4. Growth curve of the L61A strain at temperatures 60 and 70 and in $\mathrm{pH} 4$ and 6.

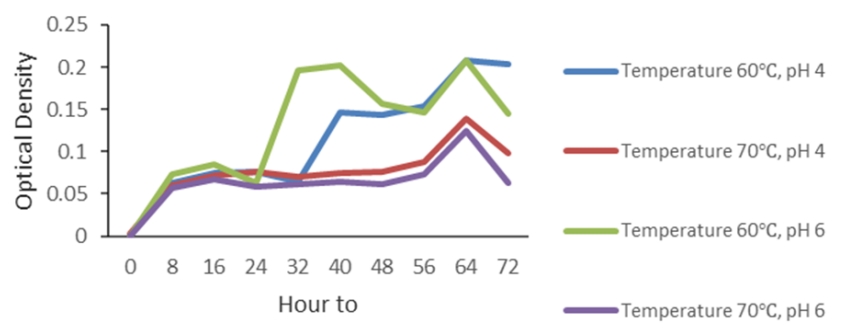

Figure 5. Growth curve of isolate D41A at temperatures $60{ }^{\circ} \mathrm{C}$ and $70^{\circ} \mathrm{C}$ and in $\mathrm{pH} 4$ and 6 . 
Table 2. The results of BLASTn sequences of 16S rRNA L61A isolates

\begin{tabular}{|c|c|c|c|c|c|c|}
\hline Accession & Description & $\begin{array}{l}\text { Max } \\
\text { score }\end{array}$ & $\begin{array}{l}\text { Total } \\
\text { score }\end{array}$ & $\begin{array}{c}\text { Query } \\
\text { coverage }(\%)\end{array}$ & $\begin{array}{c}\text { E- } \\
\text { value }\end{array}$ & $\begin{array}{c}\text { Max } \\
\text { Ident }(\%)\end{array}$ \\
\hline JQ`083173.1 & $\begin{array}{l}\text { Geobacillus sp. enrichment culture clone RA-555 16S } \\
\text { ribosomal RNA gene, partial sequence }\end{array}$ & 2,625 & 2,625 & 100 & 0.0 & 100.00 \\
\hline СР014342.1 & $\begin{array}{l}\text { Geobacillus subterraneus strain KCTC 3922, complete } \\
\text { genome }\end{array}$ & 2,619 & 2,340 & 100 & 0.0 & 99.93 \\
\hline FN428634.1 & $\begin{array}{l}\text { Geobacillus uzenensis partial } 16 \mathrm{~S} \text { rRNA gene, strain } \\
\text { LMG } 24725\end{array}$ & 2,619 & 2,619 & 100 & 0.0 & 99.93 \\
\hline AY608975.1 & $\begin{array}{l}\text { Geobacillus kaue strain BGSC W9A78 16S ribosomal } \\
\text { RNA gene, complete sequence }\end{array}$ & 2,591 & 2,591 & 100 & 0.0 & 99.93 \\
\hline JQ740260.1 & $\begin{array}{l}\text { Uncultured Geobacillus sp. clone ASC351 } 16 \mathrm{~S} \\
\text { ribosomal RNA gene, complete sequence }\end{array}$ & 2,555 & 2,553 & 100 & 0.0 & 99.09 \\
\hline FN428663.1 & $\begin{array}{l}\text { Geobacillus thermodenitrificans partial } 16 \mathrm{~S} \text { rRNA } \\
\text { gene, strain R-32619 }\end{array}$ & 2,555 & 2,553 & 100 & 0.0 & 99.02 \\
\hline
\end{tabular}

Table 3. The results of BLASTn sequences of 16S rRNA isolates of TS61A

\begin{tabular}{|c|c|c|c|c|c|c|}
\hline Accession & Description & $\begin{array}{l}\text { Max } \\
\text { score }\end{array}$ & $\begin{array}{l}\text { Total } \\
\text { score }\end{array}$ & $\begin{array}{c}\text { Query } \\
\text { coverage }(\%)\end{array}$ & $\begin{array}{c}\text { E- } \\
\text { value }\end{array}$ & $\begin{array}{c}\text { Max } \\
\text { ident }(\%)\end{array}$ \\
\hline MK133118.1 & $\begin{array}{l}\text { Uncultured Bacillus sp. Clone } 1-\mathrm{R}-1016 \mathrm{~S} \text { ribosomal } \\
\text { RNA gene, partial sequence }\end{array}$ & 942 & 942 & 100 & 0.0 & 99.24 \\
\hline MK889231.1 & $\begin{array}{l}\text { Bacillus wiedmannii strain PJH PC1 } 16 \mathrm{~S} \text { ribosomal } \\
\text { RNA gene, partial sequence }\end{array}$ & 942 & 942 & 100 & 0.0 & 99.24 \\
\hline LT838181.1 & $\begin{array}{l}\text { Bacillus thuringiensis partial 16S rRNA gene, isolate } 2 \\
\text { T22 }\end{array}$ & 942 & 942 & 100 & 0.0 & 99.24 \\
\hline MK824338.1 & $\begin{array}{l}\text { Bacterium strain BS1150 16S ribosomal RNA gene, } \\
\text { partial sequence }\end{array}$ & 942 & 942 & 100 & 0.0 & 99.24 \\
\hline LR215759.1 & Bacillus albus partial 16S rRNA gene strain AP-09-2A & 942 & 942 & $100 \%$ & 0.0 & 99.24 \\
\hline MK780061.1 & $\begin{array}{l}\text { Bacillus cereus strain SUSB7 16S ribosomal RNA } \\
\text { gene, partial sequence }\end{array}$ & 942 & 942 & 100 & 0.0 & 99.24 \\
\hline
\end{tabular}

Table 4. The results of BLASTn sequences of 16S rRNA TS61A isolates

\begin{tabular}{|c|c|c|c|c|c|c|}
\hline Accession & Description & $\begin{array}{l}\text { Max } \\
\text { score }\end{array}$ & $\begin{array}{l}\text { Total } \\
\text { score }\end{array}$ & $\begin{array}{c}\text { Query } \\
\text { coverage }(\%)\end{array}$ & $\begin{array}{c}\text { E- } \\
\text { value }\end{array}$ & $\begin{array}{c}\text { Max } \\
\text { ident }(\%)\end{array}$ \\
\hline MN319535.1 & $\begin{array}{l}\text { Bacillus paramycoides strain VITSGJ2 16S ribosomal } \\
\text { RNA gene, partial sequence }\end{array}$ & 2,575 & 2,575 & 100 & 0.0 & 99.79 \\
\hline MH489431.1 & $\begin{array}{l}\text { Bacillus sp. (in Bacteria) strain N8 16S ribosomal RNA } \\
\text { gene, partial sequence }\end{array}$ & 2,575 & 2,575 & 100 & 0.0 & 99.79 \\
\hline MN032401.1 & $\begin{array}{l}\text { Bacillus paranthracis strain RSB4B } 16 \mathrm{~S} \text { ribosomal } \\
\text { RNA gene, partial sequence }\end{array}$ & 2,575 & 2,575 & 100 & 0.0 & 99.79 \\
\hline KY930333.1 & $\begin{array}{l}\text { Bacillus cereus strain NIBSM_OsG2 } 16 \mathrm{~S} \text { ribosomal } \\
\text { RNA gene, partial sequence }\end{array}$ & 2,575 & 2,575 & 100 & 0.0 & 99.79 \\
\hline MK542825.1 & $\begin{array}{l}\text { Bacillus sp. (in: Bacteria) strain JF4 } 16 \mathrm{~S} \text { ribosomal } \\
\text { RNA gene, partial sequence }\end{array}$ & 2,575 & 2,575 & 100 & 0.0 & 99.79 \\
\hline MK780061.1 & $\begin{array}{l}\text { Bacillus cereus strain SUSB7 16S ribosomal RNA } \\
\text { gene, partial sequence }\end{array}$ & 942 & 942 & 100 & 0.0 & 99.24 \\
\hline
\end{tabular}

Site 466 in the TS61A strain showed an adenine nucleotide base while in $B$. wiedmannii, there was a gap. The gap shows the insertion or deletion of one or more of the sequence characters during evolution. The protein that is aligned should have the same three-dimensional structure. Generally, sequences in core structures such as proteins do not undergo insertion or deletion because amino acid substitution must match with the hydrophobic package environment of the core. Expectations that the gap length can occur as a result of a single introduction decides how many individual changes have occurred and the contents of the order. Site 479 in TS61A strain showed thymine nucleotide base, while in B. wiedmannii showed adenine nucleotide base.

The alignment of the L61A strain with Geobacillus uzenensis and G. kaue (Figure 7) shows the closest similarity to $G$. uzenensis. At Site 102, the L61A strain nucleotide base is the same as $G$. uzenensis, which is 
cytosine, whereas at G. kaue shows the thymine nucleotide base. Similar to site 102 , the nucleotide base shown by the L61A strain at site 667 is the same as G. uzenensis.

The alignment of the D41A strain with B. albus and $B$. paramycoides and G. kaue (Figure 8) shows the closest similarity to $B$. paramycoides. At Site 706 , the nucleotide base D41A strain is the same as B. paramycoides, namely thymine, whereas at $B$. albus, it shows cytosine nucleotide bases. Similar to site 707 to site 717 , the nucleotide base is shown by the L61A strain at site 667 is the same as $B$. paramycoides

Phylogeny analysis is one of the approaches that can be used to determine the kinship of a microorganism based on the similarity of characters. Phylogenetic trees constructed using the Neighbors Joining (NJ) method and completed with bootstrap analysis using the Kimura-Nei model (Habib et al. 2017) in MEGA 7 software. NJ is the most commonly used method derived from simplifying the minimum evolution method. Subsequent phylogenic tree construction was carried out to denote species from strains TS61A, L61A, and D41A (Figure 9).

Based on the phylogeny tree construction Figure 9, it was found that the L61A strain clustered between members of the genus Geobacillus and formed a clade with Geobacillus uzenensis (FN428634.1) while TS61A and D41A strains clustered between the genus Bacillus. TS61A forms a clade with Bacillus wiedmannii (MK889231.1) while D41A forms a clade with $B$. paramycoides (MN319535.1). Clade or cladogram is a branch of a tree formed in phylogeny used to determine the proximity of certain organisms. The formation of clades in L61A strains with Geobacillus uzenensis, TS61A with Bacillus wiedmannii and $\mathrm{D} 41 \mathrm{~A}$ with $B$. paramycoides shows that between the two in the taxonomic group that has the same ancestors.

Site 91

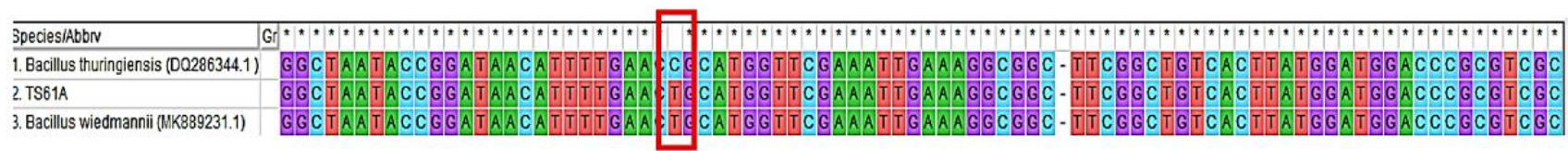

Site 418, 466, dan 479

\begin{tabular}{|c|c|c|c|c|}
\hline Species/Abbrv & Gr $\sigma^{* * * * * * * * * * * * * * * *}$ & $|* * * * * * * * * * * * * * * * * * * * * * * * * * * * *|, \mid * * * * * * * * * * * * * * * * * *$ & $* * * * * * * * * *$ & $* * * * *$ \\
\hline I. Bacillus thuringiensis (DQ286344.1) & 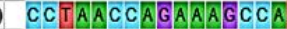 & 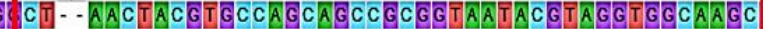 & TATCCGGAAT & $\mathrm{GGGC}$ \\
\hline ITS61A & CCTAACCAGAAAGCCA & CTACGTGCCAGCAGCCGCGGTGATACGTAGGTGGCAAGC & TATCCGGAAT & TGG GैC \\
\hline 1. Bacillus wiedmannii (MK889231.1) & CCTAACCAGAAAGCCA & ACTACGTGCCAGCAGCCGCGGTAATACGTAGGTGGCAAGC & A A T & $\mathrm{T} \mathrm{GG}$ \\
\hline
\end{tabular}

Figure 6. Alignment results of TS61 A with Bacillus thuringiensis and Bacillus wiedmannii

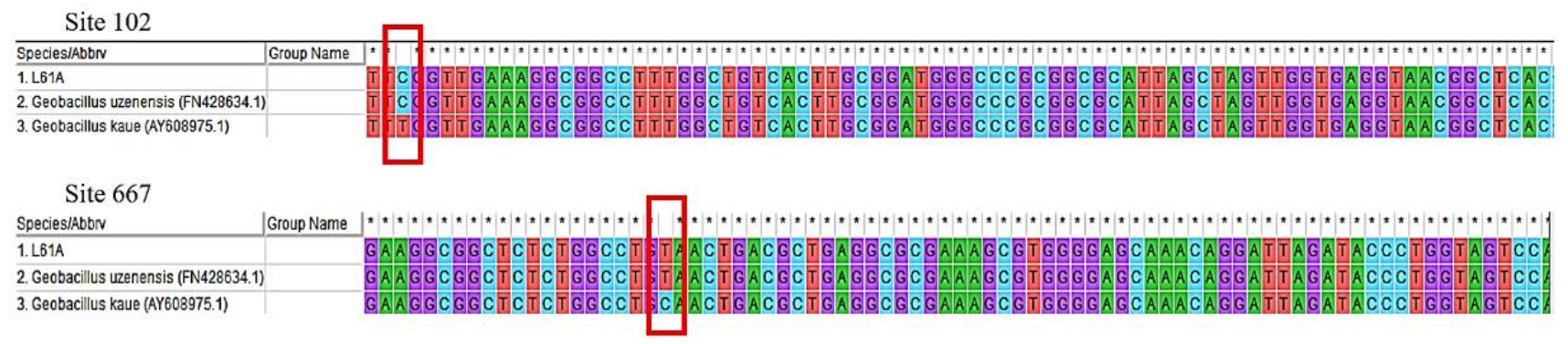

Figure. 7. L61A alignment results with Geobacillus uzenensis and G. kaue

Site 706-708, 715, dan 717

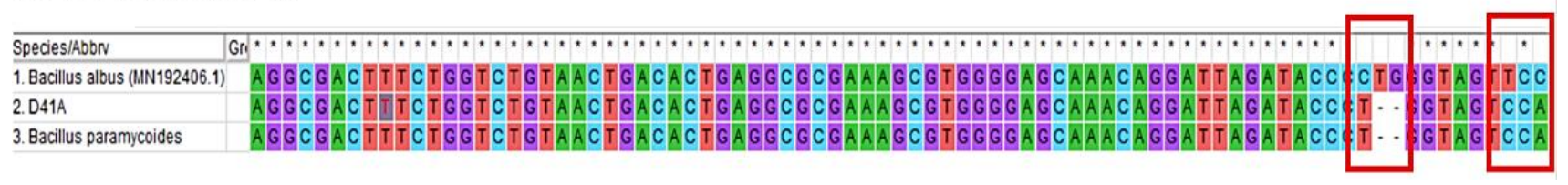

Figure 8. Alignment results of D41A with Bacillus albus and B. paramycoides 


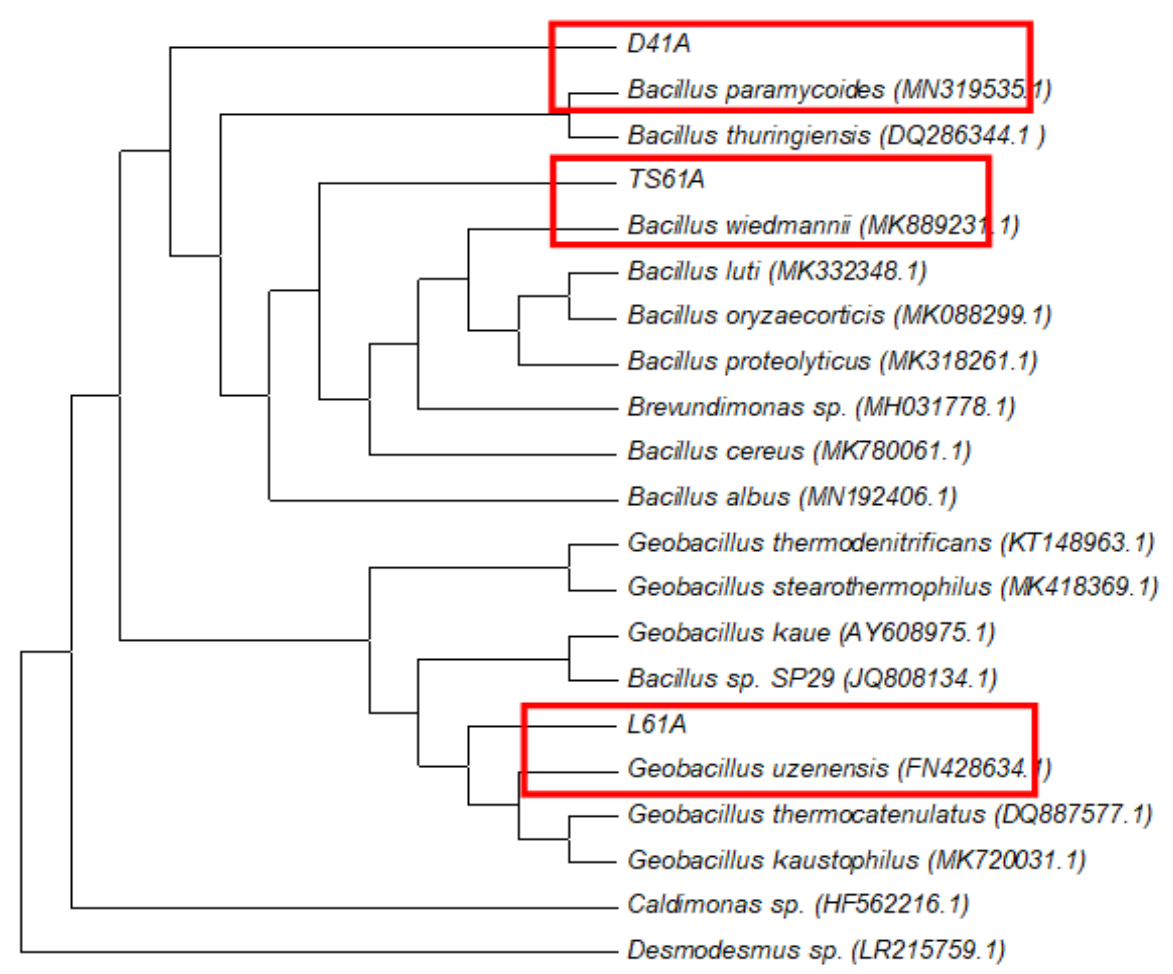

Figure 9. Phylogenetic position of isolates L61A and TS61A. The access number on GenBank for the line used is shown in parentheses

\section{Discussion}

Geothermal springs represent hot places for an unusual life, genes, and metabolites. The earth where we are living is filled with a vast and numerous variety of microorganisms, so researchers are investigating further to complete the identification and characterization of microorganisms that exist on earth. Geothermal areas are beneficial habitats for thermophilic bacteria.

In Indonesia, several hot springs are famous for the quality of rejuvenation and treatment. Temperature is often higher than $40^{\circ} \mathrm{C}$. The conditions with temperatures higher than $40^{\circ} \mathrm{C}$ cause living organisms to overcome the extreme temperatures, low humidity, and low availability of nutrient compounds. This condition reduces and selects biodiversity, but some bacteria will develop survival strategies and adapted to the pressures of these environmental conditions.

Strain TS61A is a gram-negative strain in the form of short bacilli while L61A is a gram-positive in the form of long bacilli. Both strains grow optimally at $60^{\circ} \mathrm{C}$ in medium pH 4-6 Therefore, they can be classified as thermophilic bacteria according to Niederberger (2016). The morphological and microscopic characteristics of the isolated L61A strain are similar to those of the genus Geobacillus, as described by Nazina et al. (2001) and Aliyu et al. (2016).

According to Nazina et al. (2001), Characteristic of Geobacillus was gram-positive or negative, rod-shaped in vegetative cells, motile with peritrichous flagella, and produced ellipsoidal one endospore per cell and located in the terminal in swollen or non-swollen sporangia. The colony is round, mucous, small, and colorless. TS61A strain has morphological and microscopic characteristics similar to the genus Bacillus. The Temperature range for growth $35-75^{\circ}$ (Novik et al. 2018) but for optimum at 55$65^{\circ} \mathrm{C}$. Geobacillus multiply at $\mathrm{pH} 6.0-8.5$, but in Domas crater, Geobacillus uzenensis was isolated from hot spring at $\mathrm{pH} 2$, tolerance to $\mathrm{pH} 2-7.5$ but $\mathrm{pH}$ optimum growth at pH 6. Gram staining was gram-positive or gram-negative.

The Bacillus is a genus of bacteria that can be found anywhere, even with harsher environmental conditions, in addition to its adaptation to the hot environments and $97.5 \%$ of the isolates obtained from Moroccan hot springs came from the genus Bacillus (Aanniz et al. 2015). Spores forming of Geobacillus have shown that Geobacillus resistant to heat, radiation, and chemicals. Growth at high temperatures makes Geobacillus species promising agents in biotechnological processes and as a source of various thermostable enzymes, such as proteases, amylases, lipases, and pullulanase. Geobacillus species can also produce various commercial metabolites such as exopolysaccharides and bacteriocins and take part in the production of biofuel and bioremediation (Novik et al. 2018).

Although obligate thermophiles, Geobacillus is not only found in warmest regions or naturally occurring geothermal and hydrothermal springs but also Geobacillus isolated in large numbers anywhere, even from cool soils and permanently cold ocean sediments. Geobacillus as a thermophilic chemoorganotroph has a wide range of substrates utilized, including carbohydrates, cellobiose, pentose sugars hydrocarbons, organic acids, peptones, 
tryptone, and yeast extract (Studholme 2014; Novik et al. 2018). In this study, Geobacillus isolated using the medium Thermus and Luria-Bertani.

Geobacillus, currently included in the new genus, namely Geobacillus, it forms a phylogenetically coherent clade within the family Bacillaceae. Spores of Geobacillus isolated in large quantities not only from hot environments but also from cool soils and cold ocean sediments ((Nazina et al. 2001; Zeigler, 2014). Geobacillus spp. are of interest for biotechnology as a source for thermostable enzymes and natural products, digesters of lignocellulose, bioremediation agents of hydrocarbons, producers of biofuel, cellular factories for enzymes Industrially important enzymes (Studholme 2014). Enzymes produced by Geobacillus spp. include lipases, glycoside hydrolase, Nacyl homoserine lactonase, DNA polymerase I, and protease. Most species are modest bacteria able to develop without growth factors or vitamins and to utilize n-alkanes as carbon and energy sources. The advantages of using thermophilic bacteria as a whole-cell are reduced risk of contamination, acceleration of biochemical processes, and easier maintenance of anaerobic conditions (Novik et al. 2018).

The strain of TS61A is morphologically similar to the genus Bacillus. Based on the phylogeny tree construction Figure 9, TS61A and D41A strains clustered between the genus Bacillus. TS61A forms a clade with Bacillus wiedmannii (MK889231.1). Phenotypic characterizations of $B$. wiedmannii cells were rod-shaped. Spores in the center of the vegetative cell. Colonies are grown on brain heart infusion medium (BHI, Becton Dickinson). Gramstain-positive and catalase activity were positive, motile at $30^{\circ} \mathrm{c}$. B. wiedmannii is tolerant of psychrophiles, grows at temperatures from $5^{\circ} \mathrm{C}$ to $43^{\circ} \mathrm{C}$. Growth at $\mathrm{pH} 5-10$ incubated at $30^{\circ} \mathrm{C}$ for 14 days. In a study conducted on several $B$. weidmanii strains were oxidase negative, able to hydrolyze starch and casein, facultative anaerobes, motile at $30^{\circ} \mathrm{C}$, tolerance up to $\mathrm{Nacl} 7 \%$ (Miller et al. 2016). In this study, $B$. wiedmannii can be grown and isolated using medium Thermus and Luria-Bertani (LB) at $60^{\circ} \mathrm{C}, \mathrm{pH} 4-7$, while habitat has $\mathrm{pH} 2$ and temperature at $76^{\circ} \mathrm{C}$, but temperature optimum at $60^{\circ} \mathrm{C}$.

D41A forms a clade with $B$. paramycoides (MN319535.1). The Strain of TS61A belongs to the thermophilic group of the genus Bacillus despite having a gram-negative and forming spores. $B$. paramycoides included in the Phylum Firmicutes, Class Bacilli, Order Bacillales, Family Bacillaceae, Genus Bacillus, and Species B. paramycoides (Liu et al. 2017). B. paramycoides are characterized by cell length $1.8-2.2 \mu \mathrm{m}$, width 0.8-1.2 -rod-shaped, no motile, gram reaction is positive, the colony is circular with size $2-3 \mathrm{~mm}$, incubation period in Luria Bertani agar for two days. $B$. Paramycoides grow at temperatures between $15^{\circ} \mathrm{C}-39^{\circ} \mathrm{C}$ but has an optimum temperature of $30^{\circ} \mathrm{C}$ (Liu et al. 2017). In this study, $B$. paramycoides were isolated at temperature $60^{\circ} \mathrm{C}$ at $\mathrm{pH} 6$ from hot spring, which has $76^{\circ} \mathrm{C}$ and $\mathrm{pH} 2$. However, B. paramycoides has an optimum temperature at $60^{\circ} \mathrm{C}$ and $\mathrm{pH}$ 6. Liu et al. (2017) have isolated $B$. paramycoides from four coordinates in India and one
Coordinate in Indonesia. According to Filippidou et al. (2019), cell structure can change in response to previously unknown species applying a self-protection strategy and only expressed in extreme environmental conditions.

Morphological and biochemical characterization used for identification (Table 4.1) sometimes results are difficult to interpret; therefore, complementary and accurate data are needed, namely the $16 \mathrm{~S}$ rRNA gene sequence data. The results of this study obtained the identification of thermophilic bacteria using 16S rRNA for the three strains analyzed by BLAST. Based on the BLAST alignment of these strains with the GenBank sequence, the L61A strain results obtained are $99.24 \%$ similar to Geobacillus uzenensis (FN428634.1) while 99.93\% while TS61A have similarities with Bacillus wiedmannii (MK889231.1) of $99.24 \%$, and $99.93 \%$, while TS61A has a similarity to Bacillus wiedmannii (MK889231.1) of 99.24\%, and strain D41A has $99.79 \%$ similarity with Bacillus paramycoides.

The thermophilic bacteria from the Domas Crater of Mt. Tangkuban Perahu have grown and successfully characterized optimally on LB medium and terminated $\mathrm{pH}$ 4-6 at $60^{\circ} \mathrm{C}$. L61A isolates have a high similarity with Geobacillus uzenensis. TS61A isolate has high similarity with Bacillus wiedmannii, and isolate D41A has high similarity with Bacillus paramycoides.

\section{ACKNOWLEDGEMENTS}

We would like to extend our thanks and appreciation to Rector of Universitas Padjadjaran for funding this research through the Academic Leadership Program (ALG) under the supervision of Prof. Ani Melani Maskoen. Also, we would like to express our appreciation and thanks to Prof. Shinsuke Fujiwara, Department of Bioscience, School of Science and Technology, Kwansei Gakuin University, Sanda, Hyogo, Japan, who has provided thermophile isolation training, through the Hyogo Program Earthquake Memorial 21st Century Research Institute (Hem21) Invitation Fellowship Programs for Research in Hyogo.

\section{REFERENCES}

Aanniz T, Ouadghiri M, Melloul M, Jean S, Elmostafa E, Jamal I, Mohamed I, Mohamed A. 2015. Thermophilic bacteria in Moroccan hot springs, salt marshes, and desert soils. Brazilian J Microbiol 46 (2): 443-453.

Aliyu H, Lebre PH, Blom J, Cowan DA, De Maayer P. 2016. Phylogenomic re-assessment of the thermophilic genus Geobacillus. Syst Appl Microbiol. 39: 527-533.

Bosma EF, van de Weijer AHP, Daas MJA, van der Oost J, de Vos WM, van Kranenburg R. 2015. Isolation and screening of thermophilic bacilli from compost for electrotransformation and fermentation: characterization of Bacillus smithii ET 138 as a new biocatalyst. Appl. Environ Microbiol 81:1874 -1883. DOI:10.1128/AEM.0364014.

Brouns SJJ, Etterna TJG, Stedman KM, Walther J, Smidt H, Snijders APL, Young M, Bernander R, Wright PC, Siebers B, Oost JVD. 2006. The hyperthermophilic Archaeon sulfolobus. Geothermal Biology and Geochemistry in Yellowstone National Park. https://www.researchgate.net/publication/40109833

Cihan AC, Tekin N, Ozcan B, Cokmus C. 2012. The genetic diversity of genus Bacillus and the related genera revealed by 16 s rRNA gene 
sequences and ardra analyses isolated from geothermal regions of Turkey. Brazilian J Microbiol 43 (1): 309-324.

Filippidou S, Thomas J, Tina W, Wafa MK, Ilona P, Andrej AD, Veronica M, Reto L, Jorge ES, Shannon LJ, Patrick SGC, Cristina D, Pilar J. 2019. Adaptive strategies in a poly-extreme environment: differentiation of vegetative cells in Serratia ureilytica and resistance to extreme conditions. Frontiers Microbiol 10 (102): 1-13

Habib N, Inam UK, Firasat H, Zhou EM, Xiao M, Dong L, Zhi XY, Li WJ. 2017. Meiothermus luteus sp. nov., a slightly thermophilic bacterium isolated from a hot spring. Intl J Syst Evol Microbiol 67: 2910-2914.

Handayani S, Iman S, Freisleben HJ, Harald H, Andi, Fery A, Cenmi M, Zessinda L, Rosari S, Seruni KUF, Septelia IW, Michael T. 2012. Archaeal life on Tangkuban Perahu-sampling and culture growth in Indonesian laboratories. HAYATI J Biosci 19 (3): 150-154.

Kambourova M. 2018. Thermostable enzymes and polysaccharides produced by thermophilic bacteria isolated from Bulgarian hot springs. Rev Eng Life Sci 18: 758-767.

Liu Y, Du J, Lai Q, Zeng R, Dezan Ye D, Xu J, Shao Z. 2017. Proposal of nine novel species of the Bacillus cereus group. Intl J Syst Evol Microbiol 67 (8): 2499-2508. DOI 10.1099/Ijsem.0.001821

Luthfa Z, Freisleben HJ, Saleh R. 2015. Temperature and PH-dependent molecular dynamics of Thermoplasma acidophilum tetraether lipid membrane in a computer-simulated model. Intl $\mathrm{J}$ Materials Engineering Tech. 13 (2): 161-185.

Mehta R, Singhal P, Singh H, Damle D, Sharma AK. 2016. Insight into thermophiles and their wide-spectrum applications. 3 Biotech. 6 (1): 81. DOI:10.1007/s13205-016-0368-z

Miller RA, Beno SM, Kent DJ, Carroll LM, Martin NC, Boor KJ, Kovac J. 2016. Bacillus Wiedmannii Sp. Nov., A psychrotolerant and cytotoxic Bacillus cereus group species isolated from dairy foods and dairy environments. Intl J Syst Evol Microbiol 66: 4744-4753. DOI 10.1099/ijsem.0.00142

Nazina TN, Tourova T. P, Poltaraus AB, Novikova EV, Grigoryan AA, Ivanova AE, Lysenko AM, Petrunyaka VV, Osipov GA, Belyaev SS Ivanov MV. 2001. Taxonomic study of aerobic thermophilic bacilli: descriptions of Geobacillus subterraneus gen. nov., sp. nov. and Geobacillus uzenensis sp. nov. from petroleum reservoirs and transfer of Bacillus stearothermophilus, Bacillus thermocatenulatus, Bacillus thermoleovorans, Bacillus kaustophilus, Bacillus thermodenitrificans to Geobacillus as the new combinations G. stearothermophilus, G. th Intl J Syst Evol Microbiol. 51. 433-46. DOI: 10.1099/00207713-51-2433.

Niederberger T. 2016. Extremophile. Encyclopædia Britannica. https://www.britannica.com/science/extre mophile
Novik G, Savich V, Meerovskaya O. 2019. Geobacillus bacteria: potential commercial applications in industry, bioremediation, and bioenergy production. Book Chapter: Growing and Handling of Bacterial Culture. Editors: Madhusmita Mishra IntechOpen. https://www.intechopen.com/chapter/pdf-download/61794

Paz A, Mester D, Baca I, Nevo E, Korol A. 2004. The adaptive role of increased frequency of polypurine tracts in mRNA sequences of thermophilic prokaryotes. Proceedings of the National Academy of Sciences of the United States of America 101 (9): 2951-2956. DOI: 10.1073/pnas.0308594100

Panosyan HH. 2017. Phylogenetic diversity of Thermophilic Bacilli isolated from geothermal springs of Nagorno Karabakh. Proceedings Of The Yerevan State University, Chemistry and Biology 51 (3): 179185.

Standards Unit Microbiology Services. 2018. Identification of Bacillus species. UK standards for microbiology investigations. Public Health England 9: $3.1 \mathrm{https}: / / \mathrm{www}$.gov.uk/uk-standards-for-microbiologyinvestigations-smi-quality-and-consistency-in-clinical-laboratories

Quehenberger J, Shen L, Albers S-V, Siebers B, Spadiut O. 2017. Sulfolobus - a potential key organism in future biotechnology. Front Microbiol 8: 2474. DOI: 10.3389/fmicb.2017.02474

Sambrook J, Russell DW. 2001. Molecular cloning: a laboratory manual, 3rd ed. Cold spring harbor laboratory press, cold spring harbor, N.Y.

Siso GM. 2019. Thermophiles and thermozymes. Microorganisms 7: 62. DOI: $10.3390 /$ microorganisms 7030062

Studholme DJ. 2014. Some (bacilli) like it hot: genomics of Geobacillus species. Microbial Biotechnol 8 (1): 40-48. DOI: 10.1111/17517915.12161

Tominaga Y, Ohshiro T, Suzuki H. 2016. Conjugative plasmid transfer from Escherichia coli is a versatile approach for genetic transformation of thermophilic Bacillus and Geobacillus species. Extremophiles. Springer Japan 20 (3): 375-381.

Yohandini H, Muharni J. 2015. Isolation and phylogenetic analysis of thermophile community within Tanjung Sakti Hot Spring, South Sumatera, Indonesia. HAYATI J Biosci 22:143-148

Zeigler DR, Perkins JB. 2009. The Genus Bacillus. The practical handbook of microbiology. Editors, Goldman E, Lorrence H. Green. 2nd ed. CRC Press. Taylor \& Francis Group, Boca Raton, London, New York

Zhou JF, Pei-Ke G, Xiao-Hui D, Xiao-Yu C, Hui-Mei T, Jun-Jie X, GuoQiang L, Ting M. 2016. Heavy hydrocarbon degradation of crude oil by a novel thermophilic Geobacillus stearothermophilus strain A-2. Intl Biodeterior Biodegrad 126: 224-230. 